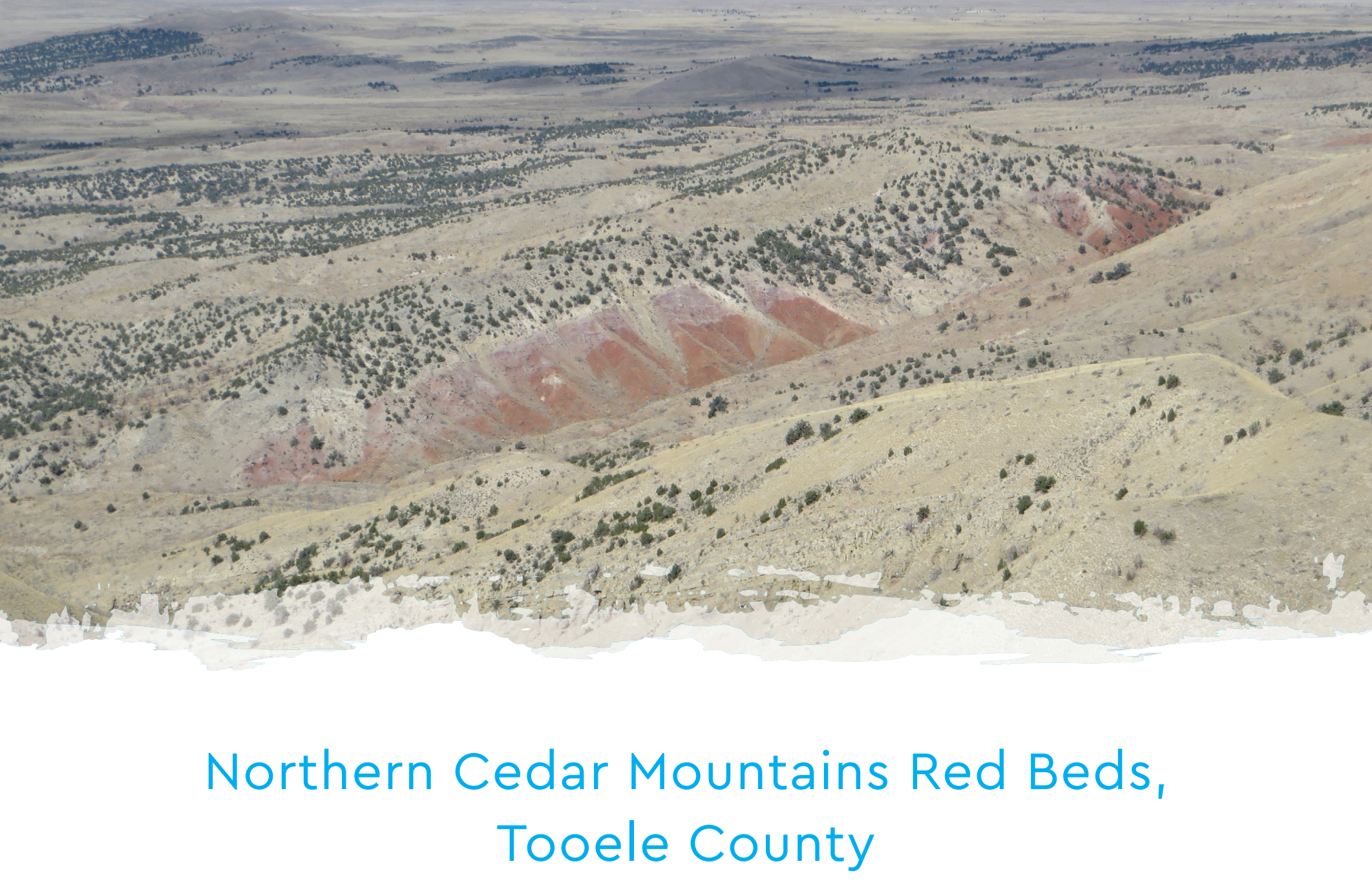

\title{
Northern Cedar Mountains Red Beds, Tooele County
}

\author{
Donald L. Clark \\ Utah Geological Survey, PO Box 146100, Salt Lake City, UT 84114-6100 \\ donclark@utah.gov
}

\section{UTAH GeOsites 2019}

Utah Geological Association Publication 48

M. Milligan, R.F. Biek, P. Inkenbrandt, and P. Nielsen, editors

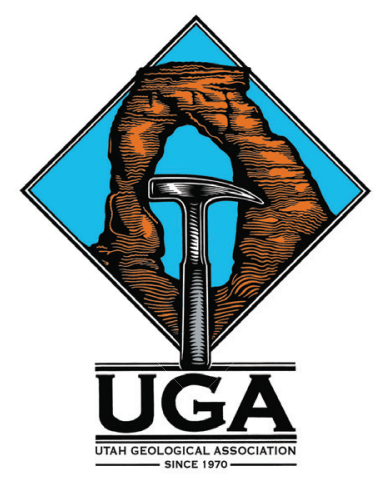

Cover Image: View to northwest, from Quincy Spring area of Cedar Mountains, to red bed Geosite. 


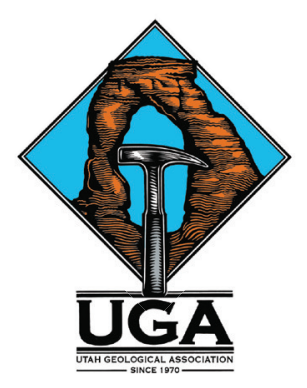

\section{Utah Geosites} 2019

\section{Utah Geological Association Publication 48}

M. Milligan, R.F. Biek, P. Inkenbrandt, and P. Nielsen, editors

Utah Geosites showcases some of Utah's spectacular geology, both little-known localities and sites seen by visitors to Utah's many national and state parks and monuments. The geosites reflect the interests of the many volunteers who wrote to share some of their favorite geologic sites. The list is eclectic and far from complete, and we hope that additional geosites will be added in the coming years. The Utah Geological Survey also maintains a list of geosites https://geology.utah.gov/apps/geosights/index.htm.

We thank the many authors for their geosite contributions, Utah Geological Association members who make annual UGA publications possible, and the American Association of Petroleum Geologists-Rocky Mountain Section Foundation for a generous grant for desktop publishing of these geosite papers.

Design and desktop publishing by Jenny Erickson, Graphic Designer, dutchiedesign.com, Salt Lake City, Utah.

This is an open-access article in which the Utah Geological Association permits unrestricted use, distribution, and reproduction of text and figures that are not noted as copyrighted, provided the original author and source are credited. See the Utah Geological Association website, www.utahgeology.org, and Creative Commons https://creativecommons.org/licenses/by/4.0/ for details.

Suggested citation for this geosite:

Clark, D.L., 2019, Northern Cedar Mountains red beds, Tooele County, in Milligan, M., Biek, R.F., Inkenbrandt, P., and Nielsen, P., editors, Utah Geosites: Utah Geological Association Publication 48, 5 p., https://doi.org/10.31711/ geosites.v1i1.57.

\section{Presidents Message}

I have had the pleasure of working with many different geologists from all around the world. As I have traveled around Utah for work and pleasure, many times I have observed vehicles parked alongside the road with many people climbing around an outcrop or walking up a trail in a canyon. Whether these people are from Utah or from another state or country, they all are quick to mention to me how wonderful our geology is here in Utah.

Utah is at the junction of several different geological provinces. We have the Basin and Range to the west and the Central Utah Hingeline and Thrust Belt down the middle. The Uinta Mountains have outcrops of some of the oldest sedimentary rock in Utah. Utah also has its share of young cinder cones and basaltic lava flows, and ancient laccoliths, stratovolcanoes, and plutonic rocks. The general public comes to Utah to experience our wonderful scenic geology throughout our state and national parks. Driving between our national and state parks is a breathtaking experience.

The "Utah Geosites" has been a great undertaking by many people. I wanted to involve as many people as we could in preparing this guidebook. We have had great response from authors that visit or work here in the state. Several authors have more than one site that they consider unique and want to share with the rest of us. I wanted to make the guidebook usable by geologists wanting to see outcrops and to the informed general public. The articles are well written and the editorial work on this guidebook has been top quality.

I would like to personally thank Mark Milligan, Bob Biek, and Paul Inkenbrandt for their editorial work on this guidebook. This guidebook could not have happened without their support. I would like to thank Jenny Erickson for doing the great desktop publishing and the many authors and reviewers that helped prepare the articles. Your work has been outstanding and will certainly showcase the many great places and geology of Utah. Last, but not least, Thank you to the American Association of Petroleum Geologists, Rocky Mountain Section Foundation for their financial support for this publication.

Guidebook 48 will hopefully be a dynamic document with the potential to add additional "geosites" in the future. I hope more authors will volunteer articles on their favorite sites. I would like to fill the map with locations so that a person or family looking at the map or articles will see a great location to read about and visit. Enjoy Guidebook 48 and enjoy the geology of Utah.

Peter J. Nielsen

2019 UGA President 


\section{INTRODUCTION}

Recent mapping for the Tooele $30^{\prime}$ x $60^{\prime}$ quadrangle geologic map revealed more information about interesting exposures of red beds cropping out in an 11-mile $(18-\mathrm{km})$ swath along the northwestern flank of the Cedar Mountains (Clark and others, 2017, 2019 in review). They are unusual because such rocks are seldom preserved in northwestern Utah, an area known for thick thrust sheets of Paleozoic marine carbonate and sandstone. These rocks were first mapped by Robert Maurer for his Ph.D. dissertation on the geology of the Cedar Mountains (Maurer, 1970). He called them North Horn (?) Formation and noted the presence of fresh-water snails (Gyraulus sp.) that a paleontologist said were probably of late Paleocene or Eocene age. The North Horn Formation is considered Late Cretaceous (Maastrichtian age) to Paleocene or Eocene ( 70 to $60 \mathrm{Ma})$ in age. However, recent detrital zircon analysis from sandstone in the unit suggest a much older age, with the youngest grains (maximum depositional age) of $117 \mathrm{Ma}$, or Early Cretaceous, Aptian (UGS and O'Sullivan, 2017). Two samples of gray mudstone taken for fossil pollen in the unit did not produce any usable material. Inspection of these rocks by Don DeBlieux (Utah Geological Survey paleontologist) revealed no bone or other biological material at this location.

\section{UNIT DESCRIPTION}

These red beds are brightly colored and stand out from the grays and browns of surrounding rocks and vegetation. The rocks (map unit Ks) consist of predominantly moderate-reddish-orange mudstone and siltstone with lenses of red and gray conglomerate and sandstone. The conglomerate clasts include sandstone, limestone, and chert that are up to 18 inches $(46 \mathrm{~cm})$ in diameter and were likely derived from Permian-age formations; northern exposures appear to be somewhat more conglomeratic. Southern exposures locally include an upper part of pink to pale purple mudstones with some interbedded coarser clastics with rapid lateral lithologic changes. Much of the outcrop belt is poorly exposed with cover by eolian sand, colluvium, and landslide debris, but exposures are as much as 1100 feet $(335 \mathrm{~m})$ thick.

\section{GEOLOGIC SIGNIFICANCE}

Assuming the Cretaceous age is correct, this is an interesting rock unit as no other Cretaceous strata are currently known from northwestern Utah. The red beds are likely similar in age to part of the Gannett Group rocks (northeastern Utah), Kelvin Formation (central Wasatch Mountains), and the Cedar Mountain Formation (eastern Utah).

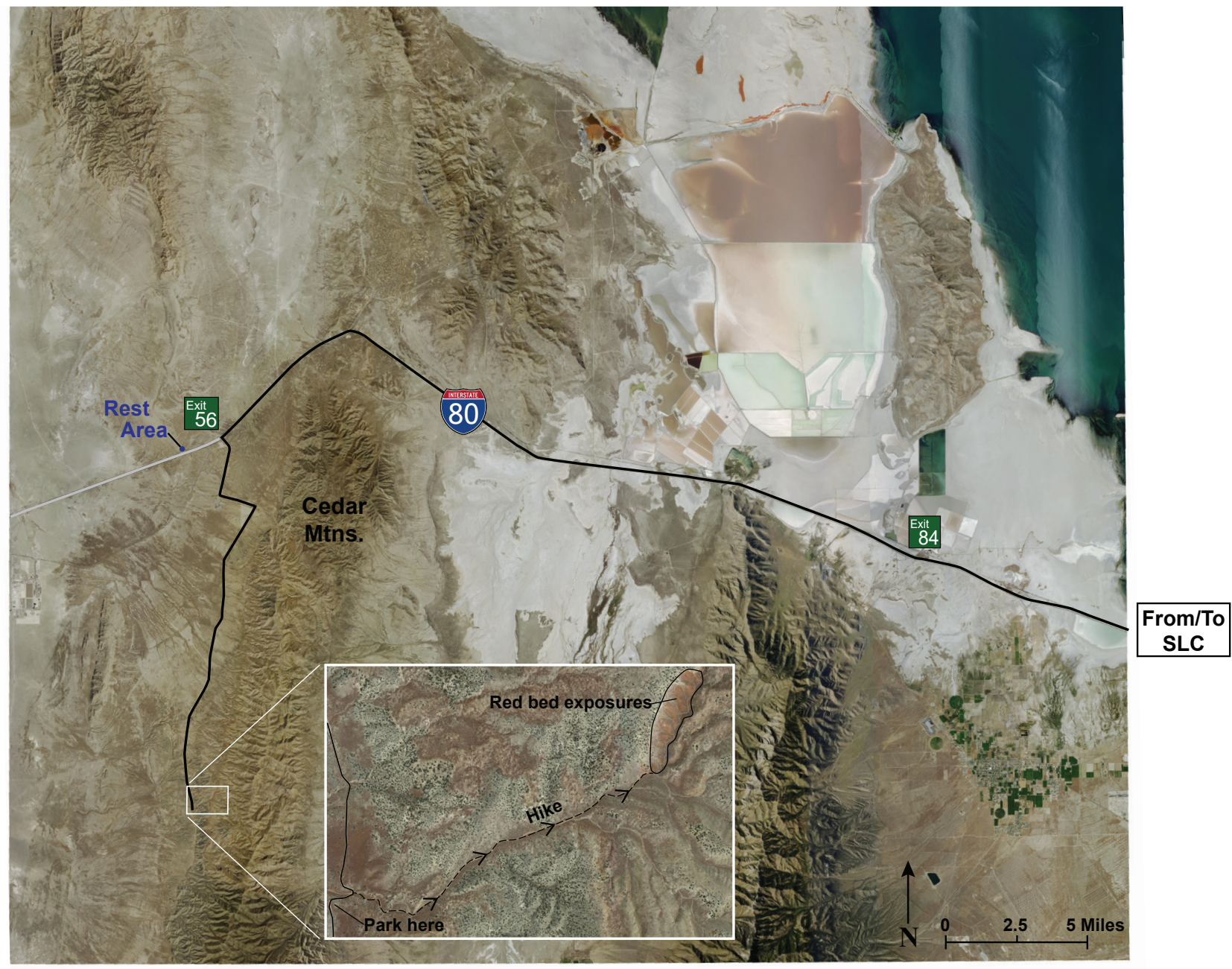

Figure 1. geosite location map. SLC is Salt Lake City. 
Also of interest is the location of the red beds; these rocks are wedged between two thrust sheets of the Sevier fold-thrust belt (see, for example, Willis, 1999; Hintze and Kowallis, 2009, p. 68). The Cedar thrust fault (carrying Pennsylvanian Oquirrh Group rocks, map unit Polc) lies directly on the red beds and below are Permian rocks (Gerster and Plympton Formations, map unit Pgp) belonging to a different unnamed thrust sheet. A tremendous thickness of conglomerate and sandstone were shed eastward of the fold-thrust belt and are preserved in northeastern Utah, but this relatively small expanse of red beds was likely deposited in a piggyback (wedgetop) basin of the orogenic belt. The existence of the red beds constrains emplacement of the Cedar thrust sheet to no earlier than Early Cretaceous (Aptian). Thrust sheets of the Sevier orogenic belt were emplaced from about 130 to $50 \mathrm{Ma}$ (Early Cretaceous to early Eocene) across northern Utah (Yonkee and Weil, 2011).
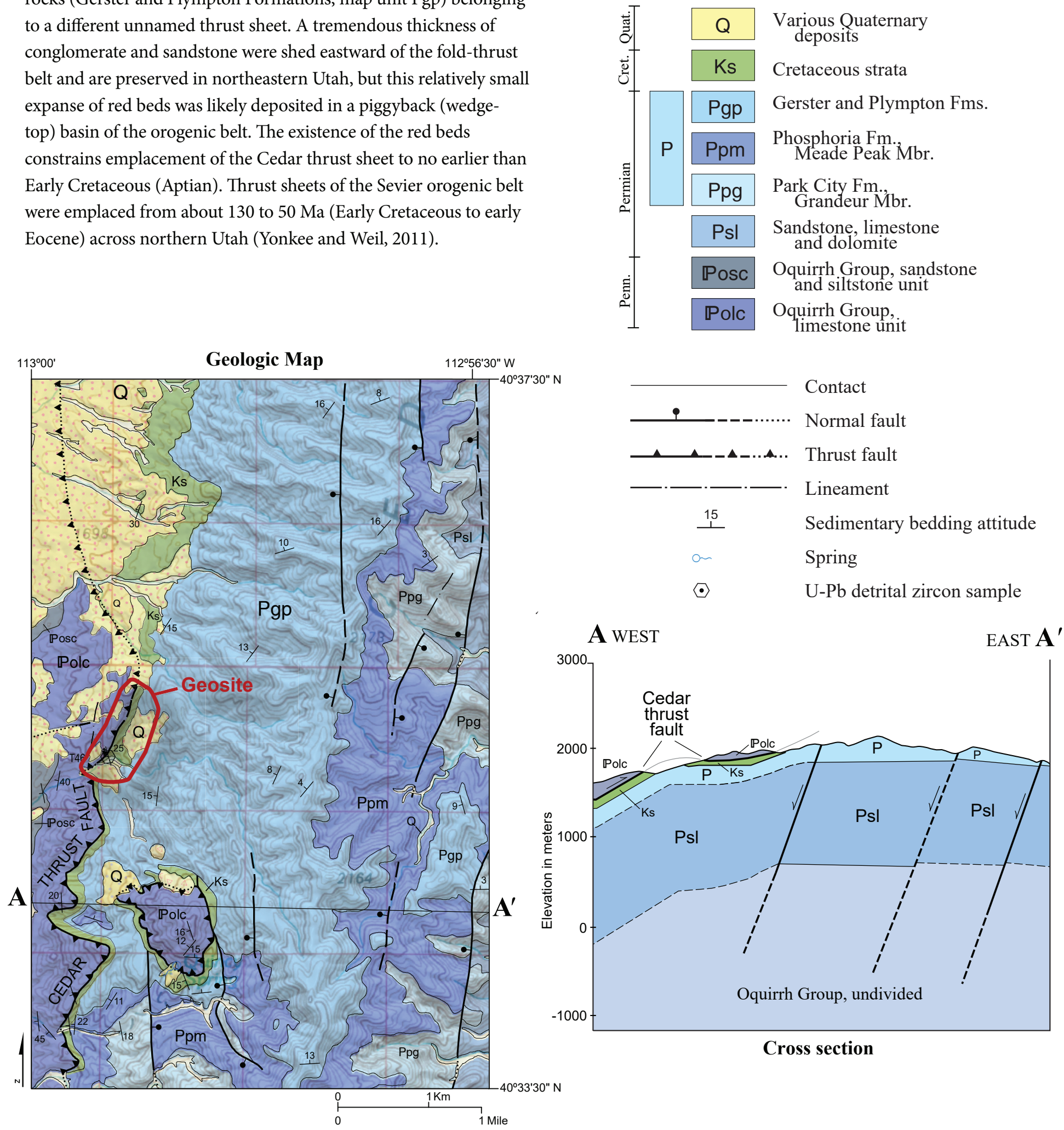

Figure 2. Part of the Tooele 30' $\times 60^{\prime}$ geologic map and cross section, from Clark and others (2017, 2019 in review). 


\section{HOW TO GET THERE}

Take I-80 west from Salt Lake City. Continue to Exit 56 Aragonite. At top of ramp, turn left (south) cross I-80 on paved road to the Clean Harbors Hazardous Waste Incinerator facility. Turn left (east) before incinerator onto gravel road. Continue east, to BLM signboard and sign for Cedar Mountains Wilderness. Turn right (south) on gravel road (Cedar Mountains road). Continue 12 miles $(19 \mathrm{~km})$ south, cross cattle guard. Continue and pass by wash bottom. The road is too narrow for safe parking, so continue 0.25 mile $(0.4 \mathrm{~km})$ south, turn around on dirt road to right (west) leading to a water trough. Come back to the north and park along the east side of the road before the wash bottom (Latitude $40.57995^{\circ} \mathrm{N}$, Longitude $\left.113.00459^{\circ} \mathrm{W}, \mathrm{WGS} 84\right)$. Enter Cedar Mountains Wilderness area and hike east along drainage about 1 mile $(1.6 \mathrm{~km})$ to exposure of red beds $\left(\sim 40.58470^{\circ} \mathrm{N}, 112.99034^{\circ} \mathrm{W}\right.$, WGS84).

\section{ACKNOWLEDGMENTS}

Geologic mapping was supported by the STATEMAP component of the National Cooperative Geologic Mapping Program. I thank UGS staff Zach Anderson and Don DeBlieux, and UGA editors Mark Milligan and Robert Biek for reviews of this paper. Thanks also to Lori Steadman and Martha Jensen (UGS) for preparation of the figures. Basia Matyjasik (UGS) compiled the Geographic Information System data for the Tooele 30' x 60' geologic map.

\section{REFERENCES}

Clark, D.L., Oviatt, C.G., and Dinter, D.A., 2017, Interim geologic map of the Tooele 30' x 60' quadrangle, Tooele, Salt Lake, and Davis Counties, Utah: Utah Geological Survey Open-File Report 669DM, 43 p., 3 plates, contains GIS data, scale 1:62,500.

Clark, D.L., Oviatt, C.G., and Dinter, D.A., 2019 in review, Geologic map of the Tooele 30' x 60' quadrangle, Tooele, Salt Lake, and Davis Counties, Utah: Utah Geological Survey Map, scale 1:62,500.

Hintze, L.F., and Kowallis, B.J., 2009, Geologic history of Utah: Brigham Young University Geology Studies, Special Publication 9, 225 p.

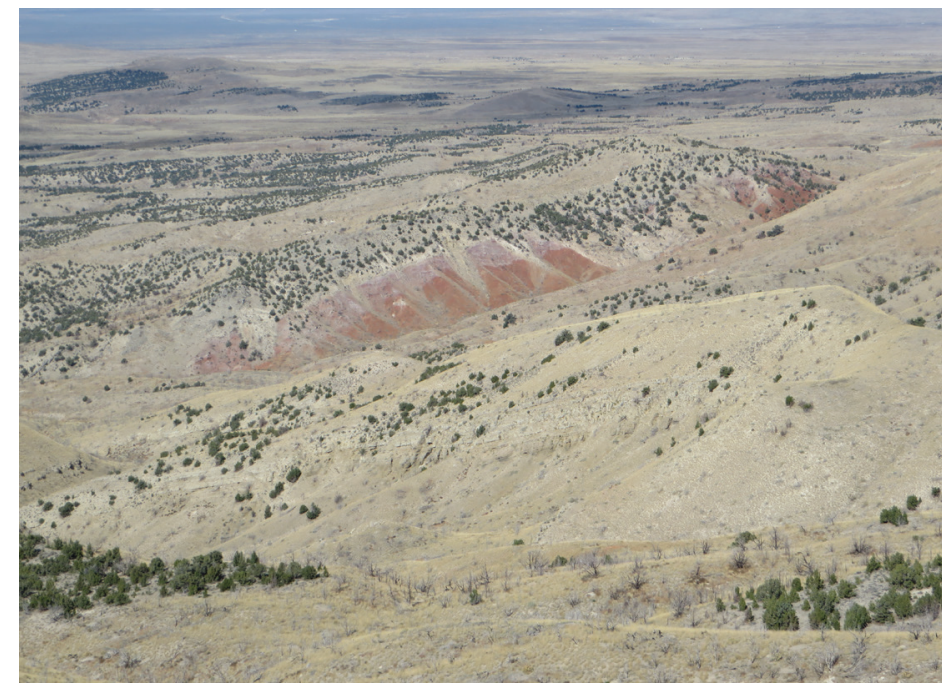

Figure 3. View northwest of Lower Cretaceous red beds from the Quincy Spring area of the Cedar Mountains.

Maurer, R.E., 1970, Geology of the Cedar Mountains, Tooele County, Utah: Salt Lake City, University of Utah, Ph.D. dissertation, 184 p., 10 plates, scale 1:43,700.

Utah Geological Survey and O'Sullivan, P.B., 2017, U-Pb zircon geochronology results for the Angle, Donkey Flat, Farnsworth Peak, Fort Douglas, and Quincy Spring quadrangles, Utah: Utah Geological Survey Open-File Report 660, variously paginated, online, http://ugspub.nr.utah.gov/publications/ open_file_reports/ofr-660/ofr-660.pdf.

Willis, G.C., 1999, The Utah thrust system-an overview, in Spangler, L.E. and Allen, C.J., editors, Geology of northern Utah and vicinity: Utah Geological Association Publication 27, p. 1-9.

Yonkee, W.A., and Weil, A.B., 2011, Evolution of the Wyoming salient of the Sevier fold-thrust belt, northern Utah to western Wyoming, in Sprinkel, D.A., Yonkee, W.A., and Chidsey, T.C., Jr., editors, Sevier thrust belt-northern and central Utah and adjacent areas: Utah Geological Association Publication 40, $56 \mathrm{p}$.

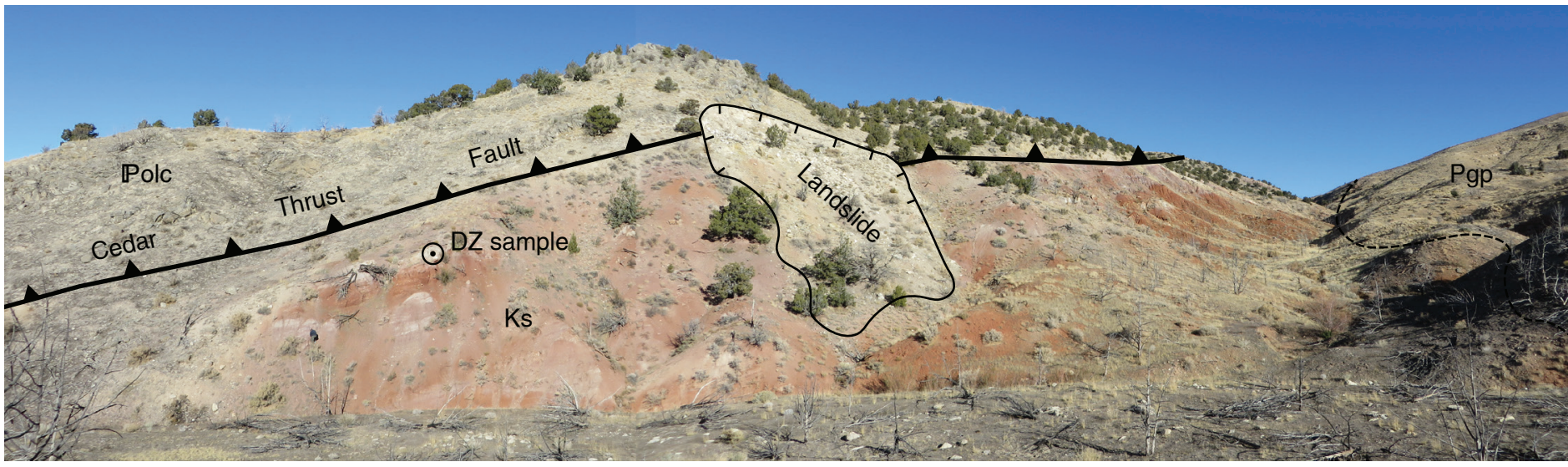

Figure 4. View to northwest of red beds. Ks = Cretaceous strata, $\mathbb{P o l c}=$ Oquirrh Group, limestone unit of Cedar thrust sheet. Pgp=Gerster and Plympton Formations . $\mathrm{DZ}$ is $\mathrm{U}$-Pb detrital zircon sample location. 